\title{
Analisis Potensi Likuifaksi Akibat Gempa (Studi Kasus : Reklamasi Pelabuhan Kontainer Belawan Fase-2)
}

\author{
Mario HUTAGALUNG ${ }^{1} * \cdot$ Simon Dertha TARIGAN $^{2} *$ \\ ${ }^{1}$ Program Studi Teknik Sipil Universitas Katolik Santo Thomas \\ ${ }^{2}$ Staf Pengajar Teknik Sipil Universitas Katolik Santo Thomas
}

\begin{abstract}
One of the impacts caused by an earthquake is the strength loss of the soil due to cyclic stresses called liquefaction. Liquifaction usually occurs in loose sand. The objective of this study is to determine the potential of liquefaction in observed project. The project observed in this study is reclamation project. Analysis for potential liquefaction is done using the Simplified Procedure Method. Firstly, determine the value of peak acceleration in bedrock in the study area based on the 2010 Indonesian Earthquake Hazard Map. Secondly, collect soil data based on CPT-u testing. Based on these data, the acceleration value (Amplification/Deamplification) can be found on each soil layer when being moved from the bedrock to the ground surface. By comparing the average shear stress caused by the acceleration of the earthquake to the effective vertical stress at each soil layer, we can obtain the value of Cyclic Stress Ratio. Lastly, calculate CRR (Cyclic Resistant Ratio) which is the value of soil resistance to liquefaction. Based on CRR value, it can be seen the corrected conus penetration value (qc1N). The three parameters are then connected in the NCEER 1996 chart to assess which soil layers are potentially liquefied or not during an earthquake.
\end{abstract}

Kata kunci: prefabricated vertical drain, PLAXIS, reklamasi

\section{Pendahuluan}

Indonesia termasuk daerah yang memiliki aktivitas gempa yang tinggi. Hal ini disebabkan lokasi Indonesia yang terletak pada pertemuan empat lempeng tektonik utama bumi yaitu Lempeng Eurasia, Indo-Australia, Pasifik dan Philipina. Oleh sebab itu, setiap perencanaan pembangunan di Indonesia, sangat perlu memperhitungkan resiko - resiko yang disebabkan oleh terjadinya gempa. Resiko - resiko tersebut, bukanlah hanya resiko yang terjadi pada kegagalan struktur bangunan saja, namun juga resiko kegagalan yang akan terjadi pada struktur tanah yang mendukung / menopang beban di atasnya.

Dalam penelitian ini, penulis akan membahas salah satu kegagalan yang terjadi pada struktur tanah sehingga menjadikan tanah tersebut tidak memiliki kekuatan untuk mendukung / menopang beban di atasnya yang disebut likuifaksi. Likuifaksi adalah proses hilangnya kekuatan tanah akibat tegangan air pori yang timbul akibat beban siklis (berulang). Sehingga tegangan tanah total hampir seluruhnya digantikan oleh tegangan air pori.

Perhitungan likuifaksi pada umumnya dilakukan pada tanah yang memiliki gradasi buruk seperti sandy poor (SP) atau yang disebut dengan pasir lepas, karena pada tanah seperti ini lebih banyak berpotensi menyimpan air dibandingkan dengan tanah yang bergradasi baik.

*penulis korespondensi

e-mail:simondertha2003@yahoo.com 


\section{Tinjauan Pustaka}

\section{Gempa Tektonik}

Menurut para ahli, gempa tektonik sebenarnya terjadi karena adanya pergeseran lempengan di dalam bumi, sehingga akibat pergeseran lempengan tersebut tentu akan menyebabkan getaran ke permukaan bumi. Kapan terjadi pergeseran itu tidak bisa diketahui secara pasti. Tempat terjadinya pergeseran itu disebut sebagai hypocenter atau focus ataupun pusat gempa, sedangkan proyeksi garis tegak lurus hypocenter terhadap permukaan bumi disebut sebagai epicenter.

Derformasi yang disebabkan oleh terjadinya interaksi antar lempeng dapat berupa subduction yang merupakan interaksi antar lempeng yang tebalnya hampir sama, dimana lempeng pertama tenggelam di bawah lempeng kedua. Biasanya terjadi di sepanjang busur pulau dan transcursion yang merupakan interaksi antar dua lempeng, dimana keduanya bergerak horizontal satu terhadap yang lainnya. Keduanya dapat berupa lempeng laut atau antara lempeng laut dengan lempeng benua, serta extrucsio yang merupakan interaksi antara dua lempeng tipis yang bergerak saling menjauh.

Pergerakan dari patahan atau sesar dapat dibedakan berdasarkan dua arah pergerakan yaitu strike slip movement yang merupakan pergerakan patahan yang terjadi mempunyai arah sejajar dengan garis strike di mana bidang patahan mendekati vertikal dan menyebabkan pergerakan besar. Sedangkan dip slip movement merupakan pergerakan patahan mempunyai arah yang sejajar dengan kemiringan (slope) dip atau tegak lurus dengan strike. Jenis patahan ini dibagi dua yaitu normal fault dan reverse fault.

\section{Cone Penetration Test Dengan Pressure Measurement (CPTu)}

$\mathrm{CPTu}$ adalah uji sondir elektris yang disertai pengukuran tekanan air pori (pressure measurement) atau sering disebut sebagai piezocone penetrometer test. Pembacaan konus $\mathrm{CPTu}$ dapat membedakan berapa persentase beban yang dipikul oleh tanah dan air. Piezocone terdiri dari ujung konus, elemen pori, selimut sondir, penahan air (water seals), penahan tanah (soil seals), batang sondir dan alat pembaca.

Bentuk standar piezocone mengikuti standar sondir mekanis dengan luas area konus $10 \mathrm{~cm}^{2}$, radius konus $3.56 \mathrm{~cm}$, sudut konus $60^{\circ}$ dan luas selimut $150 \mathrm{~cm}^{2}$ serta kecepatan penetrasi standar adalah $2 \mathrm{~cm} /$ detik.

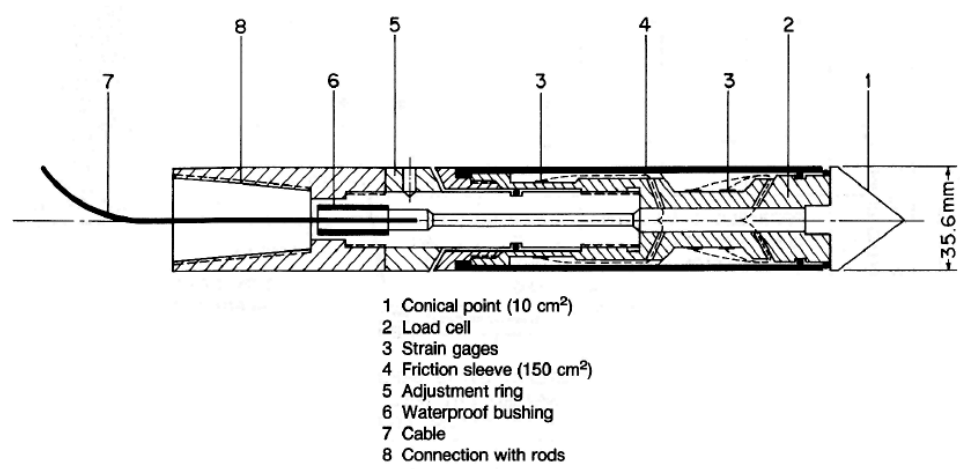

Gambar 1 Bikonus sondir elektris (Piezocone) 
Untuk menentukan jenis tanah pada saat pengujian CPTu, digunakan chart yang diusulkan oleh Robertson et al (1986), yang menghubungkan antara corrected cone resistence (qt) terhadap friction ratio (FR) serta qt terhadap Bq.
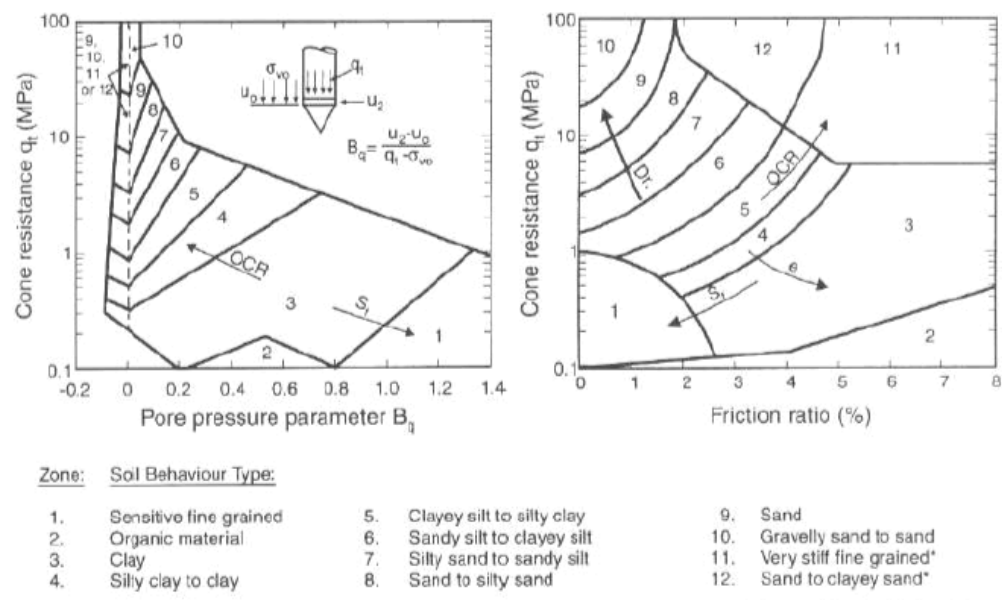

$$
\begin{aligned}
& \text { 5. Clayey silt to silty clay } \\
& \text { 6. Sandy silt to clayey silt } \\
& \text { 7. Silty sand to sandy silt }
\end{aligned}
$$

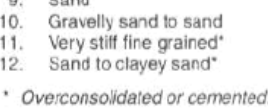

Gambar 2 Grafik penentuan jenis tanah menurut Robertson et al (1986)

Dalam studi penelitian ini, data penyelidikan tanah pada lokasi studi kasus diperoleh berdasarkan pengujian $\mathrm{CPTu}$, namun tetap dibutuhkan nilai N-SPT dalam menentukan parameter - parameter tanah lanjutan. Nilai N-SPT tersebut dapat diperoleh berdasarkan korelasi antara nilai qc yang didapatkan dari pengujian CPTu dengan nilai $\mathrm{N}$ dari SPT.

Berikut adalah korelasi antara nilai qc terhadap nilai $\mathrm{N}$, yang dikemukakan oleh Terzaghi dan Peck (1976) $: \mathrm{qc}=4 \mathrm{~N}$, dimana qc : Nilai perlawanan penetrasi konus

$\mathrm{N}$ : Nilai SPT.

\section{Definisi Likuifaksi}

Likuifaksi merupakan fenomena hilangnya kekuatan lapisan tanah akibat tegangan air pori yang timbul akibat beban siklis (getaran). Getaran yang dimaksud dapat berupa getaran yang berasal dari gempa bumi maupun yang berasal dari pembebenan cepat lainnya.

Ketika mengalami getaran tersebut sifat lapisan tanah berubah menjadi seperti cairan sehingga tak mampu menopang beban bangunan di dalam atau di atasnya.

Likuifaksi biasanya terjadi pada tanah yang jenuh air, dimana seluruh rongga - rongga dari tanah tersebut dipenuhi oleh air. Pada saat mengalami getaran, air ini memberikan suatu tekanan di partikel-partikel tanah sehingga mempengaruhi kepadatan dari tanah tersebut.

Sebelum terjadinya gempa bumi, tekanan air pada suatu tanah secara relatif rendah. Namun setelah menerima getaran, tekanan air dalam tanah meningkat, sehingga dapat menggerakkan partikel- partikel tanah dengan mudah.

Setelah digerakkan oleh air, maka partikel tanah tidak memiliki lagi kekuatan atau daya dukung, sehingga daya dukung tanah sepenuhnya berasal dari tegangan air pori. Pada kondisi ini, tanah sudah berbentuk cairan yang tidak lagi memiliki kestabilan, sehingga beban - beban yang ada di atas tanah tersebut seperti beban dari struktur bangunan akan amblas ke dalam 
tanah. Sebaliknya tangki - tangki yang berada di dalam tanah akan mengapung dan muncul kepermukaan tanah.

\section{Tegangan Vertikal Total}

Tegangan vertikal total merupakan tegangan pada lapisan tanah yang diakibatkan oleh beban dari tanah yang ada di atasnya tanpa memperhitungkan tegangan air pori yang diakibatkan oleh air $(\mu)$. Semakin jauh kedalaman tanah maka semakin besar tegangan vertikal totalnya. Tegangan vertikal total dapat dihitung dengan rumus dibawah ini :

$$
\sigma_{\mathrm{v}}=\sum(\gamma \times \mathrm{z})
$$

Dimana :

$\sigma_{\mathrm{v}}:$ Tegangan vertikal total $\left(\mathrm{KN} / \mathrm{m}^{2}\right)$

$\gamma$ : Berat isi lapisan tanah $\left(\mathrm{KN} / \mathrm{m}^{3}\right)$

$\mathrm{z}$ : Kedalaman lapisan tanah $(\mathrm{m})$

\section{Tegangan Vertikal Efektif}

Tegangan vertikal Efektif merupakan tegangan pada lapisan tanah yang diakibatkan oleh beban dari tanah yang ada di atasnya dengan memperhitungkan tegangan air pori yang diakibatkan oleh air $(\mu)$. Tegangan air pori membuat tekanan yang berasal dari beban tanah menjadi berkurang.

$$
\sigma^{\prime} \mathrm{v}=\sigma \mathrm{V}-\mu
$$

Dimana :

$$
\begin{array}{ll}
\sigma_{\mathrm{v}} & : \text { Tegangan vertikal efektif }\left(\mathrm{KN} / \mathrm{m}^{2}\right) \\
\sigma_{\mathrm{v}} & : \text { Tegangan vertikal total }\left(\mathrm{KN} / \mathrm{m}^{2}\right) \\
\mu & : \text { Tegangan air pori }\left(\mathrm{KN} / \mathrm{m}^{2}\right)=\gamma_{\mathrm{w}} \cdot \mathrm{z} \\
\gamma_{\mathrm{w}} & : \text { Berat isi air }\left(\mathrm{KN} / \mathrm{m}^{3}\right) \\
\mathrm{z} & : \text { Kedalaman lapisan tanah }(\mathrm{m})
\end{array}
$$

Tabel 1 Korelasi nilai N-SPT terhadap berat isi

\begin{tabular}{|c|c|c|c|c|}
\hline \multicolumn{5}{|c|}{ Non Kohesif } \\
\hline $\mathrm{N}$ & $0-10$ & $11-30$ & $31-50$ & $>50$ \\
\hline$\gamma\left(\mathrm{KN} / \mathrm{m}^{3}\right)$ & $12-16$ & $14-18$ & $16-20$ & $18-23$ \\
\hline State & Loose & Medium & Dense & Very Dense \\
\hline
\end{tabular}

\begin{tabular}{|c|c|c|c|c|c|}
\hline \multicolumn{6}{|c|}{ Kohesif } \\
\hline $\mathrm{N}$ & $<4$ & $4-6$ & $6-15$ & $16-25$ & $>25$ \\
\hline$\gamma\left(\mathrm{KN} / \mathrm{m}^{3}\right)$ & $14-18$ & $16-18$ & $16-18$ & $16-20$ & $>20$ \\
\hline State & Very Loose & Soft & Medium & Stiff & Hard \\
\hline
\end{tabular}

(Sumber : Sosrodarsono, 1977)

\section{Percepatan Puncak Pada Batuan Dasar (PGA)}

Percepatan puncak pada batuan dasar (PGA) dapat ditentukan berdasarkan Peta Hazard Gempa Indonesia. Dalam hal ini penulis menggunakan Peta Hazard Gempa Indonesia 2010 yaitu peta percepatan puncak (PGA) dengan level gempa 2\% dalam 50 tahun (Gempa 2500 
tahun) dan dikontrol berdasarkan informasi yang disediakan oleh Puslitbang Pemukiman KEMENPUPR, www.puskim.pu.go.id/Aplikasi/desain_spektra_indonesia_2011/.

\section{Percepatan Pada Permukaan Tanah ( $a_{\max }$ )}

Perhitungan percepatan pada permukaan tanah $\left(\mathrm{a}_{\max }\right)$ memiliki perbedaan dengan perhitungan percepatan puncak di batuan dasar (PGA). Dalam perhitungan analisis percepatan pada permukaan tanah harus menganalisis lapisan tanah pada lokasi penelitian, dalam hal ini data lapisan tanah diperoleh berdasarkan pengujian CPTu

Pada studi ini, penulis akan menggunakan Program software edushake untuk menghitung percepatan pada permukaan tanah untuk lokasi yang akan ditinjau.

Edushake adalah sebuah program yang diperuntukkan membantu mahasiswa agar mengetahui mekanika dari pergerakan seismik pada tanah. Analisis pada lapisan tanah dilakukan dengan 3 langkah yaitu :

Input manager. Dalam input manager, penulis memasukkan data yang akan diolah seperti data profil tanah dan data karakteristik gempa.

Solution manager. Setelah memasukkan data, kemudian akan diolah pada menu ini.

Output manager. Pada output manager, hasil dari analisis akan ditampilkan sesuai dengan yang pengguna inginkan. Output manager memberikan hasil analisis dalam beberapa bentuk seperti time history, response spectra, variasi beberapa parameter dan juga animasi dari horizontal displacement pada lapisan tanah.

\section{Modulus Geser Maksimum ( $\left.G_{\max }\right)$}

Sifat dan penyebaran kerusakan akibat gempa terutama dipengaruhi oleh respons tanah terhadap beban siklik. Dalam hal ini respons tersebut adalah percepatan maksimum pada setiap lapisan tanah. Percepatan tersebut dipengaruhi oleh parameter tanah, yaitu parameter dinamik tanah. Parameter dinamik tanah tersebut adalah modulus geser maksimum (Gmax) dan kecepatan rambat gelombang geser (Vs).

Dalam penelitian ini, penulis menggunakan korelasi yang dikemukakan oleh Seed et al (1983), yaitu : Gmax $=6220 . \mathrm{N}(\mathrm{kPa})$ Dimana nilai kecepatan rambat gelombang gesernya (Vs) akan dikorelasi secara otomatis dalam program software edushake, ketika memasukkan nilai Gmax setiap lapisan tanah pada menu input manager.

\section{Nilai qc Terkoreksi ( $\left.q c_{1 N}\right)$}

Tahanan penetrasi CPTu pada pasir meningkat dengan kenaikan confining stress, dimana nilai qc dari kedalaman dan lokasi pengujian tidak bisa dibandingkan satu sama lainnya secara langsung. Oleh karena itu nilai qc harus dikoreksi.

Berikut adalah persamaan untuk mendapatkan faktor koreksi qc menurut Robertson dan Wride (1996) dalam metode NCEER (National Center of Earthquake Engineering Research) 1996 :

$$
C_{Q}=\left(\frac{P a}{\sigma^{\prime} v}\right)^{0.5} \leq 1.7
$$


Dimana :

$\mathrm{C}_{\mathrm{Q}} \quad$ : Faktor koreksi

$\mathrm{Pa}:$ Tekanan atmosfir $\left( \pm 100 \mathrm{KN} / \mathrm{m}^{2}\right)$

$\sigma^{\prime} \mathrm{v}$ : Tegangan vertikal efektif $\left(\mathrm{KN} / \mathrm{m}^{2}\right)$

Sehingga, diperoleh :

$$
\mathrm{q}_{\mathrm{c} 1 \mathrm{~N}}=\mathrm{C}_{\mathrm{Q}} \cdot\left(\frac{\mathrm{qc}}{\mathrm{Pa}}\right)
$$

\section{Nilai qc Terkoreksi $\left(q c_{1 N}\right)$}

Faktor reduksi adalah koefisien reduksi tegangan dan tidak mempunyai dimensi. Faktor reduksi akan berkurang apabila kedalaman lapisan tanah bertambah. Faktor reduksi ini bergantung pada magnitude gempa (Idriss, 1999). Untuk kebutuhan praktis di lapangan, nilai $r_{d}$ biasanya diambil dari kurva average values by Seed and Idriss (1971).

Langkah lain yang dapat dilakukan adalah dengan mengasumsikan hubungan linear antara $r_{d}$ dan kedalaman (Seed and Idriss, 1971) dengan menggunakan persamaan :

$r_{d}=1-(0.00765) .(z)$ untuk $z \leq 9.15 \mathrm{~m}$

$\mathrm{r}_{\mathrm{d}}=1.174-(0.0267) .(z)$ untuk $9.15 \mathrm{~m}<\mathrm{z}<23 \mathrm{~m}$

$\mathrm{r}_{\mathrm{d}}=0.744-(0.008) .(z)$ untuk $23 \mathrm{~m}<\mathrm{z}<30 \mathrm{~m}$

$\mathrm{r}_{\mathrm{d}}=0.5$ untuk $\mathrm{z} \geq 30 \mathrm{~m}$

Dengan $\mathrm{z}$ adalah kedalaman tanah yang digunakan untuk analisis likuifaksi (dan juga digunakan dalam perhitungan tegangan).

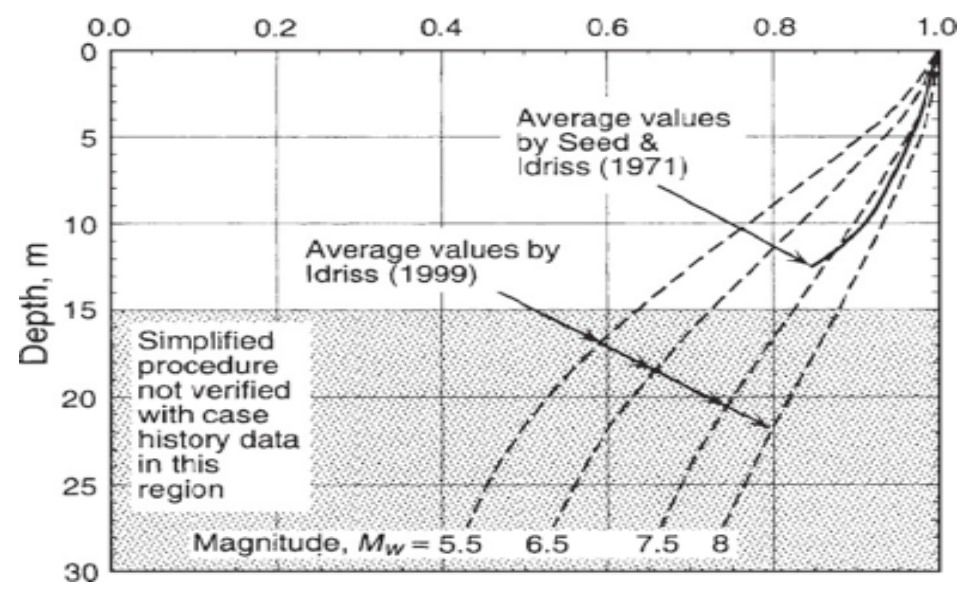

Gambar 3 Faktor reduksi $\left(r_{d}\right)$ terhadap kedalaman (Seed and Idriss, 1971)

\section{Nilai qc Terkoreksi $\left(q c_{1 N}\right)$}

CSR adalah nilai perbandingan antara tegangan geser rata-rata yang diakibatkan oleh gempa dengan tegangan vertikal efektif di setiap lapisan tanah. CSR juga biasa disebut Seismic Stress Ratio (SSR). 


$$
\operatorname{CSR}=0.65 .\left(\frac{a \max }{g}\right) .\left(\frac{\sigma v}{\sigma^{\prime} v}\right) . r_{d}
$$

Dimana :

$$
\begin{array}{ll}
\text { CSR } & \text { : Cyclic Stress Ratio (tidak berdimensi) } \\
\mathrm{a}_{\max } & \text { : Percepatan maksimum di permukaan tanah } \\
\mathrm{g} & \text { : Percepatan gravitasi } \\
\mathrm{S}^{\prime} \mathrm{v} & \text { : Tegangan vertikal efektif } \\
\mathrm{SV} & \text { : Tegangan vertikal total } \\
\mathrm{r}_{\mathrm{d}} & \text { : Faktor reduksiahanan penetrasi CPT }
\end{array}
$$

\section{Cyclic Resistance Ratio (CRR)}

Nilai Cyclic Resistance Ratio (CRR) merupakan nilai ketahanan suatu lapisan tanah terhadap tegangan siklis. Nilai CRR dapat diperoleh dengan berdasarkan hasil pengujian lapangan. Dalam hal ini, penulis menganalisis nilai CRR berdasarkan hasil pengujian Piezo Cone Penetration Test (CPTu) pada nilai qc terkoreksi $\left(\mathrm{q}_{\mathrm{c} 1 \mathrm{~N}}\right)$.

Berdasarkan metode NCEER (National Center of Earthquake Engineering Research) 1996, Robertson dan Wride (1996) mengusulkan persamaan berikut dalam menentukan nilai CRR :

$$
\begin{array}{ll}
\text { Jika }\left(\mathrm{q}_{\mathrm{c} 1 \mathrm{~N}}\right)<50, & \mathrm{CRR}_{7.5}=0.833\left[\left(\mathrm{q}_{\mathrm{c} 1 \mathrm{~N}}\right) / 1000\right]+0.05 \\
\text { Jika } 50 \leq\left(\mathrm{q}_{\mathrm{c} 1 \mathrm{~N}}\right)<160, & \mathrm{CRR}_{7.5}=93\left[\left(\mathrm{q}_{\mathrm{c} 1 \mathrm{~N}}\right) / 1000\right]^{3}+0.08
\end{array}
$$

Dimana :

$\mathrm{q}_{\mathrm{c} 1 \mathrm{~N}} \quad$ : Nilai qc terkoreksi $\left(\mathrm{Kg} / \mathrm{cm}^{2}\right)$

$\mathrm{CRR}_{7.5}$ : Cyclic Resistance Ratio magnitude 7.5

\section{Metodologi}

\section{Lokasi Penelitian}

Reklamasi Pelabuhan Kontainer Belawan terletak di Timur Laut pantai Sumatera, sekitar 27 kilometer dari Kota Medan yang merupakan Ibukota Provinsi Sumatera Utara. Reklamasi tersebut merupakan bagian dari kawasan pelabuhan Belawan, yang berada pada semenanjung antara Sungai Belawan dan Sungai Deli dan merupakan pelabuhan utama yang dikelola oleh PT. PELINDO I. Pekerjaan reklamasi tersebut dilakukan untuk nantinya difungsikan sebagai lapangan penumpukan kontainer atau peti kemas, dengan elevasi ketinggian timbunan $+3,5$ LWS. 


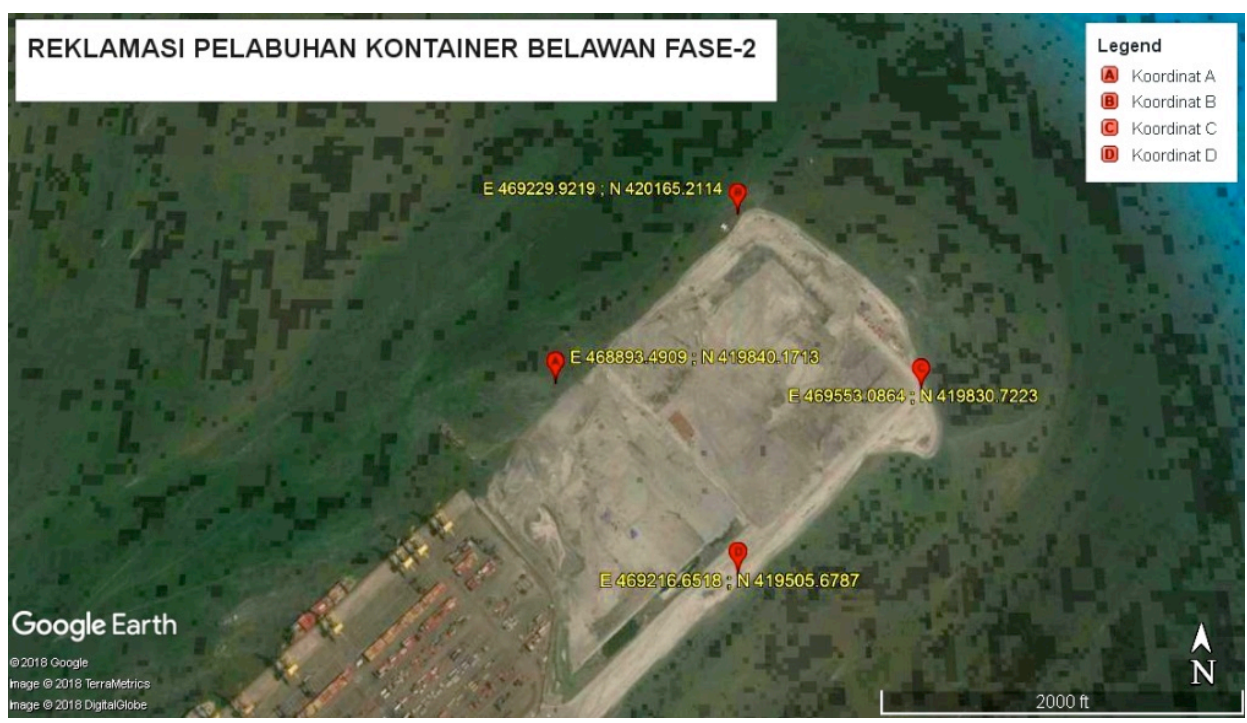

Gambar 4 Lokasi Penelitian

\section{Data Tanah}

Pengambilan data tanah untuk proses analisis dilakukan di beberapa titik di lokasi Reklamasi Pelabuhan Kontainer Belawan, melalui pengujian CPTu. Pekerjaan investigasi tanah dilakukan pada tanggal 1 September 2017 sampai 17 September 2017, dengan kedalaman \pm 16 meter.

\section{Parameter Tanah}

Seluruh data tanah yang diperoleh kemudian diolah berdasarkan korelasi - korelasi yang ada untuk menentukan parameter tanah pada setiap titik pengujian untuk digunakan dalam analisis. Parameter - parameter tanah tersebut adalah :
a. Berat isi tanah
b. Tegangan vertikal total
c. Tegangan vertikal efektif
d. Modulus geser maksimum
e. Nilai qc terkoreksi $\left(\mathrm{q}_{\mathrm{c} 1 \mathrm{~N}}\right)$
f. Faktor reduksi

\section{Metode NCEER (National Center of Earthquake Engineering Research) 1996}

Dengan menghubungkan nilai CSR dan CRR serta $\mathrm{q}_{\mathrm{c} 1 \mathrm{~N}}$ pada grafik NCEER (1996), maka akan diketahui lapisan lapisan tanah mana yang akan terlikuifaksi. Apabila titik hubungan antara CSR dan $\mathrm{q}_{\mathrm{c} 1 \mathrm{~N}}$ pada suatu lapisan tanah berada di bawah kurva CRR, maka lapisan tersebut aman terhadap likuifaksi. Namun sebaliknya, apabila titik tersebut berada di atas kurva, maka lapisan tanah tersebut akan terlikuifaksi. Grafik NCEER (1996) tersedia dalam magnitude 7.5 M. Oleh karena itu, jika magnitude gempa yang mengakibatkan percepatan maksimum pada permukaan tanah tidak bernilai $7.5 \mathrm{M}$, maka untuk menggunakan grafik ini, nilai CSR harus dikalikan dengan nilai koreksi. Nilai koreksi dapat dihitung dengan menggunakan nilai faktor koreksi. 
Tabel 2 Faktor koreksi magnitude untuk pendekatan tegangan siklis

\begin{tabular}{|c|c|}
\hline Magnitude Gempa & $\boldsymbol{C S}_{\boldsymbol{M}} / \boldsymbol{C S}_{\boldsymbol{M}=\mathbf{7 . 5}}$ \\
\hline 5.25 & 1.5 \\
\hline 6 & 1.32 \\
\hline 6.75 & 1.13 \\
\hline 7.5 & 1.00 \\
\hline 8.5 & 0.89 \\
\hline
\end{tabular}

(Sumber : Seed et al (1985), Reprodeuksi dari Robert (2002))

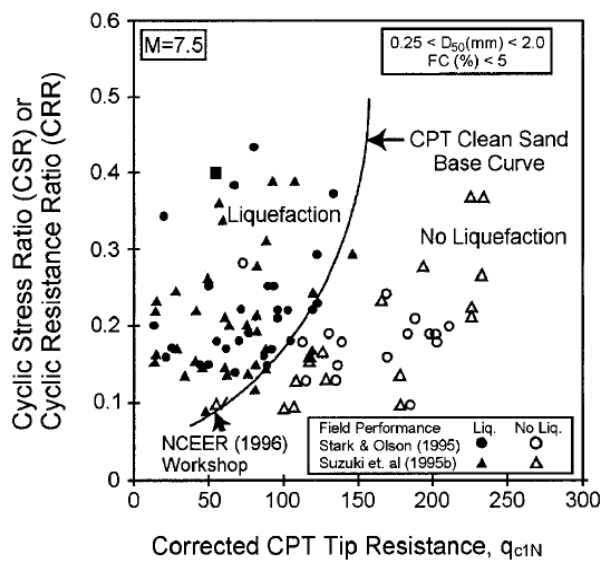

Gambar 5 Hubungan antara CSR/CRR dan $\mathrm{q}_{\mathrm{c} 1 \mathrm{~N}}$

\section{Analisis dan Pembahasan}

\section{Pemeriksaan Tanah}

Potensi terjadinya likuifaksi sangat rentan terjadi pada tanah pasir (nonkohesif) dalam keadaan lepas serta jenuh air. Berdasarkan investigasi CPTu yang dilakukan Geotechnical Engineering Consultant (GEC), diketahui bahwa tebal lapisan tanah pasir di setiap titik pengujian $\pm 4 \mathrm{~m}$ dan selebihnya adalah berjenis lempung dan lempung berlanau. Berdasarkan syarat potensi likuifaksi yang telah dibahas pada bab sebelumnya, maka potensi likuifaksi hanya dikaji pada lapisan pasir saja (nonkohesif).

Sebelum menganalisis potensi likuifaksi, maka hasil investigasi tanah disederhanakan dengan pembagian lapisan - lapisan tanah pasir setiap $0.5 \mathrm{~m}$ seperti pada tabel - tabel berikut.

Tabel 3 Data pemeriksaan tanah di lokasi CPTu-1

\begin{tabular}{|c|c|c|c|c|c|c|}
\hline $\begin{array}{c}\text { Titik } \\
\text { Pengujian } \\
\text { di } \\
\text { Lapangan }\end{array}$ & No. & Jenis Tanah & $\begin{array}{c}\text { Kedalaman } \\
\text { (m) }\end{array}$ & $\begin{array}{c}\text { Tebal } \\
\text { Tanah } \\
\text { (m) }\end{array}$ & $\begin{array}{c}\text { qc } \\
\text { (Mpa) }\end{array}$ & $\begin{array}{c}q c \\
\left(\mathrm{Kg} / \mathrm{cm}^{2}\right)\end{array}$ \\
\hline \multirow{7}{*}{$\begin{array}{c}\text { CPTu-1 } \\
\text { M. Air } \\
\text { Tanah : } \\
2.5 \mathrm{~m}\end{array}$} & 1 & Sand to silty sand & 0.5 & 0.5 & 2.92 & 29.25 \\
\hline & 2 & Sand to silty sand & 1.0 & 0.5 & 6.68 & 66.79 \\
\hline & 3 & Sand to silty sand & 1.5 & 0.5 & 5.93 & 59.29 \\
\hline & 4 & Sand to silty sand & 2.0 & 0.5 & 6.59 & 65.85 \\
\hline & 5 & Sand to silty sand & 2.5 & 0.5 & 7.32 & 73.18 \\
\hline & 6 & Sand to silty sand & 3.0 & 0.5 & 7.44 & 74.35 \\
\hline & 7 & Sand to silty sand & 3.5 & 0.5 & 6.28 & 62.81 \\
\hline
\end{tabular}




\begin{tabular}{|c|c|c|c|c|c|c|}
\hline $\begin{array}{c}\text { Titik } \\
\text { Pengujian } \\
\text { di } \\
\text { Lapangan }\end{array}$ & No. & Jenis Tanah & $\begin{array}{c}\text { Kedalaman } \\
\text { (m) }\end{array}$ & $\begin{array}{c}\text { Tebal } \\
\text { Tanah } \\
\text { (m) }\end{array}$ & $\begin{array}{c}\text { qc } \\
\text { (Mpa) }\end{array}$ & $\begin{array}{c}q \mathrm{c} \\
\left(\mathrm{Kg} / \mathrm{cm}^{2}\right)\end{array}$ \\
\hline & 8 & Sand to silty sand & 4.0 & 0.5 & 4.21 & 42.08 \\
\hline & 9 & Clay & 15.0 & 11.0 & 0.31 & 3.10 \\
\hline & 10 & Silty Clay to Clay & 16.44 & 1.44 & 0.40 & 4.00 \\
\hline
\end{tabular}

Tabel 4 Data pemeriksaan tanah di lokasi CPTu-2

\begin{tabular}{|c|c|c|c|c|c|c|}
\hline $\begin{array}{c}\text { Titik } \\
\text { Pengujian } \\
\text { di } \\
\text { Lapangan }\end{array}$ & No. & Jenis Tanah & $\begin{array}{c}\text { Kedalaman } \\
\text { (m) }\end{array}$ & $\begin{array}{c}\text { Tebal } \\
\text { Tanah } \\
\text { (m) }\end{array}$ & $\begin{array}{c}\text { qc } \\
\text { (Mpa) }\end{array}$ & $\begin{array}{c}q \mathrm{c} \\
\left(\mathrm{Kg} / \mathrm{cm}^{2}\right)\end{array}$ \\
\hline \multirow{10}{*}{$\begin{array}{c}\text { CPTu-2 } \\
\text { M. Air } \\
\text { Tanah : } \\
1.5 \mathrm{~m}\end{array}$} & 1 & Sand to silty sand & 0.5 & 0.5 & 2.98 & 29.81 \\
\hline & 2 & Sand to silty sand & 1.0 & 0.5 & 6.14 & 61.38 \\
\hline & 3 & Sand to silty sand & 1.5 & 0.5 & 7.37 & 73.68 \\
\hline & 4 & Sand to silty sand & 2.0 & 0.5 & 10.74 & 107.45 \\
\hline & 5 & Sand & 2.5 & 0.5 & 8.37 & 83.65 \\
\hline & 6 & Sand & 3.0 & 0.5 & 6.91 & 69.06 \\
\hline & 7 & Sand & 3.5 & 0.5 & 7.29 & 72.87 \\
\hline & 8 & Sand & 4.0 & 0.5 & 6.05 & 60.51 \\
\hline & 9 & Clays & 15.00 & 11.00 & 0.41 & 4.10 \\
\hline & 10 & Silty Clay to Clay & 16.42 & 1.42 & 0.40 & 3.96 \\
\hline
\end{tabular}

Tabel 5 Data pemeriksaan tanah di lokasi CPTu-3

\begin{tabular}{|c|c|c|c|c|c|c|}
\hline $\begin{array}{c}\text { Titik } \\
\text { Pengujian } \\
\text { di } \\
\text { Lapangan } \\
\end{array}$ & No. & Jenis Tanah & $\begin{array}{c}\text { Kedalaman } \\
\text { (m) }\end{array}$ & $\begin{array}{c}\text { Tebal } \\
\text { Tanah } \\
\text { (m) }\end{array}$ & $\begin{array}{c}\text { qc } \\
\text { (Mpa) }\end{array}$ & $\begin{array}{c}q c \\
\left(\mathrm{Kg} / \mathrm{cm}^{2}\right)\end{array}$ \\
\hline \multirow{9}{*}{$\begin{array}{c}\text { CPTu-3 } \\
\text { M. Air } \\
\text { Tanah : } 2 \\
\text { m }\end{array}$} & 1 & Sand to silty sand & 0.5 & 0.5 & 4.37 & 43.71 \\
\hline & 2 & Sand to silty sand & 1.0 & 0.5 & 10.59 & 105.86 \\
\hline & 3 & Sand to silty sand & 1.5 & 0.5 & 7.91 & 79.13 \\
\hline & 4 & Sand to silty sand & 2.0 & 0.5 & 6.12 & 61.17 \\
\hline & 5 & Sand to silty sand & 2.5 & 0.5 & 5.89 & 58.86 \\
\hline & 6 & Sand to silty sand & 3.0 & 0.5 & 4.63 & 46.32 \\
\hline & 7 & Sand to silty sand & 3.5 & 0.5 & 4.09 & 40.85 \\
\hline & 8 & Sand to silty sand & 4.0 & 0.5 & 6.04 & 60.40 \\
\hline & 9 & Clays & 16.35 & 12.35 & 0.56 & 5.56 \\
\hline
\end{tabular}

Tabel 6 Data pemeriksaan tanah di lokasi CPTu-4

\begin{tabular}{|c|c|c|c|c|c|c|}
\hline $\begin{array}{c}\text { Titik } \\
\begin{array}{c}\text { Pengujian } \\
\text { di } \\
\text { Lapangan }\end{array}\end{array}$ & No. & Jenis Tanah & $\begin{array}{c}\text { Kedalaman } \\
(\mathrm{m})\end{array}$ & $\begin{array}{c}\text { Tebal } \\
\text { Tanah } \\
(\mathrm{m})\end{array}$ & $\begin{array}{c}\mathrm{qc} \\
(\mathrm{Mpa})\end{array}$ & $\begin{array}{c}\mathrm{qc} \\
\left(\mathrm{Kg} / \mathrm{cm}^{2}\right)\end{array}$ \\
\hline & 1 & Sand to silty sand & 0.50 & 0.50 & 3.08 & 30.77 \\
\cline { 2 - 7 } & 2 & Sand to silty sand & 1.00 & 0.50 & 5.44 & 54.40 \\
\cline { 2 - 7 } CPTu-4 & 3 & Sand to silty sand & 1.50 & 0.50 & 3.67 & 36.66 \\
$\begin{array}{c}\text { M. Air } \\
\text { Tanah }: 1 \\
\text { m }\end{array}$ & 4 & Sand to silty sand & 2.00 & 0.50 & 2.67 & 26.71 \\
\cline { 2 - 7 } & 5 & Sand to silty sand & 2.50 & 0.50 & 4.49 & 44.92 \\
\cline { 2 - 7 } & 7 & Sand to silty sand & 3.00 & 0.50 & 4.12 & 41.20 \\
\hline
\end{tabular}




\begin{tabular}{|c|c|l|c|c|c|c|}
\hline 8 & Sand to silty sand & 4.00 & 0.50 & 3.36 & 33.60 \\
\hline & 9 & Sand to silty sand & 4.50 & 0.50 & 2.89 & 28.85 \\
\hline 10 & Sand to silty sand & 5.00 & 0.50 & 2.18 & 21.75 \\
\hline 11 & Sand to silty sand & 5.50 & 0.50 & 1.95 & 19.45 \\
\hline 12 & Clays & 15.00 & 9.50 & 0.31 & 3.14 \\
\hline & 13 & Silty clay to clay & 16.32 & 1.32 & 0.44 & 4.44 \\
\hline
\end{tabular}

\section{Percepatan Puncak Pada Batuan Dasar (PGA)}

Nilai percepatan puncak pada batuan dasar ditentukan berdasarkan Peta Hazard Gempa Indonesia 2010. Dalam hal ini peta yang digunakan adalah peta percepatan puncak (PGA) di batuan dasar untuk probabilitas terlampaui $2 \%$ dalam 50 tahun (2500 tahun), secara langsung melalui website resmi puskim PUPR dengan input lokasi penelitian yaitu Belawan.

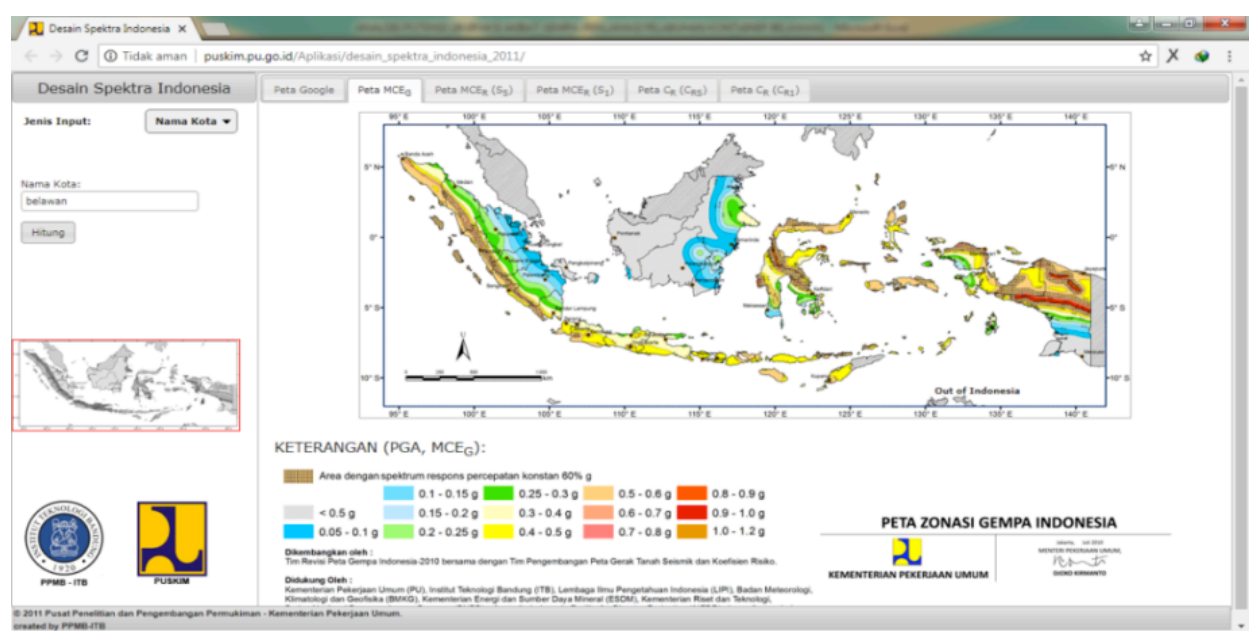

Gambar 6 Input lokasi penelitian dalam website Puskim PUPR

Dengan input tersebut, dilanjutkan dengan proses sehingga diperoleh nilai percepatan puncak pada batuan dasar (PGA) di lokasi penelitian yaitu sebesar $0.213 \mathrm{~g}$.

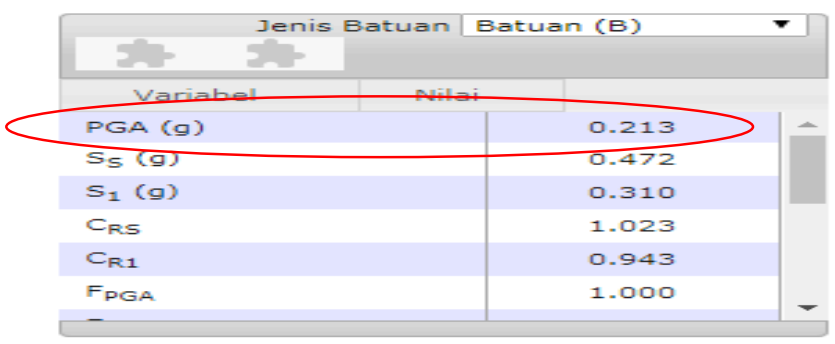

Gambar 7 Hasil nilai PGA dari website Puskim PUPR

\section{Percepatan Pada Permukaan Tanah ( $a_{\max }$ )}

Dalam perhitungan ini, penulis menggunakan percepatan puncak pada batuan dasar yang telah diperoleh sebelumnya yaitu $0.213 \mathrm{~g}$. Percepatan tersebut akan diuji pada lokasi penelitian dengan menggunakan karakteristik gempa Elcentro. 


\section{Karakteristik gempa Percepatan puncak pada batuan dasar (PGA)}

\section{Elcentro}

$$
0.213 \mathrm{~g}
$$

Perhitungan nilai percepatan pada permukaan tanah menggunakan program software edushake. Parameter yang dibutuhkan adalah kedalaman muka air tanah, tebal lapisan tanah, berat isi lapisan tanah, nilai modulus geser maksimum $\left(G_{\max }\right)$ dan kecepatan rambat gelombang geser (Vs), dimana nilai Vs akan ditentukan secara otomatis dalam program software edushake.

Perhitungan percepatan pada permukaan tanah dalam program software edushake adalah sebagai berikut. Pada input motion, dipilih karakteristik gempa Elcentro dengan merubah nilai PGA nya menjadi nilai PGA Belawan.

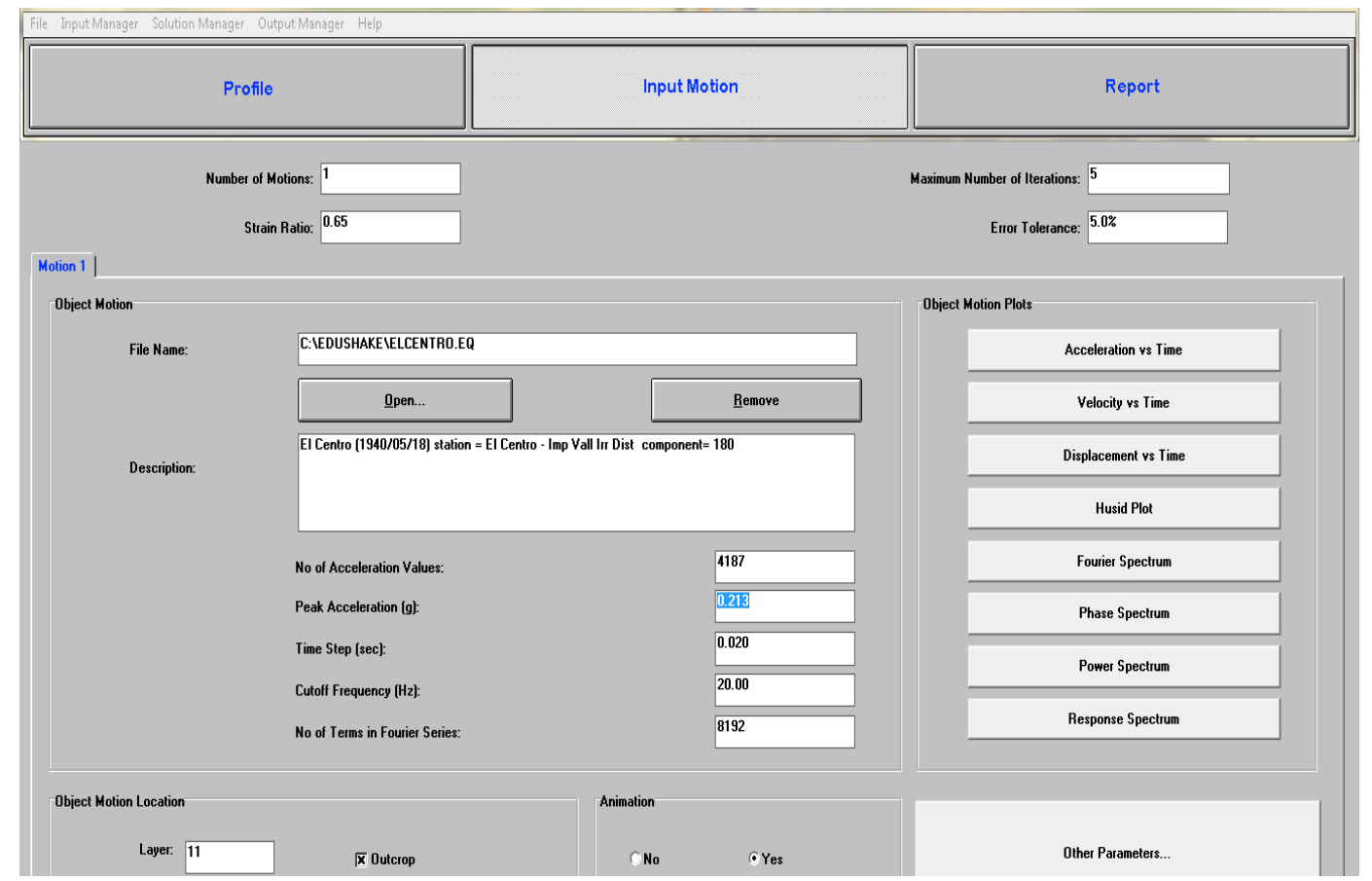

Gambar 8 Input percepatan puncak pada batuan dasar dengan karakteristik Gempa Elcentro 


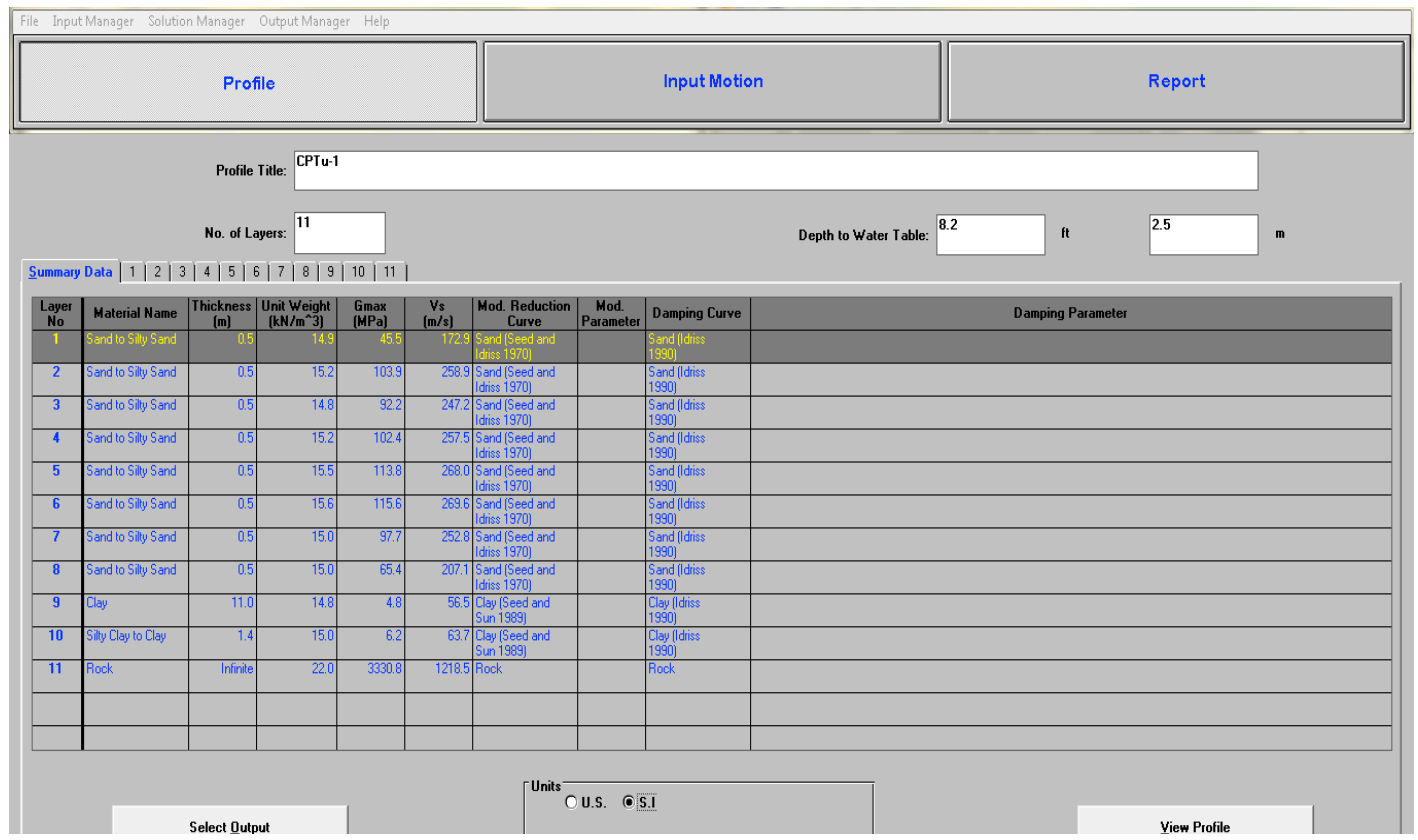

Gambar 9 Input jenis lapisan tanah CPTu-1

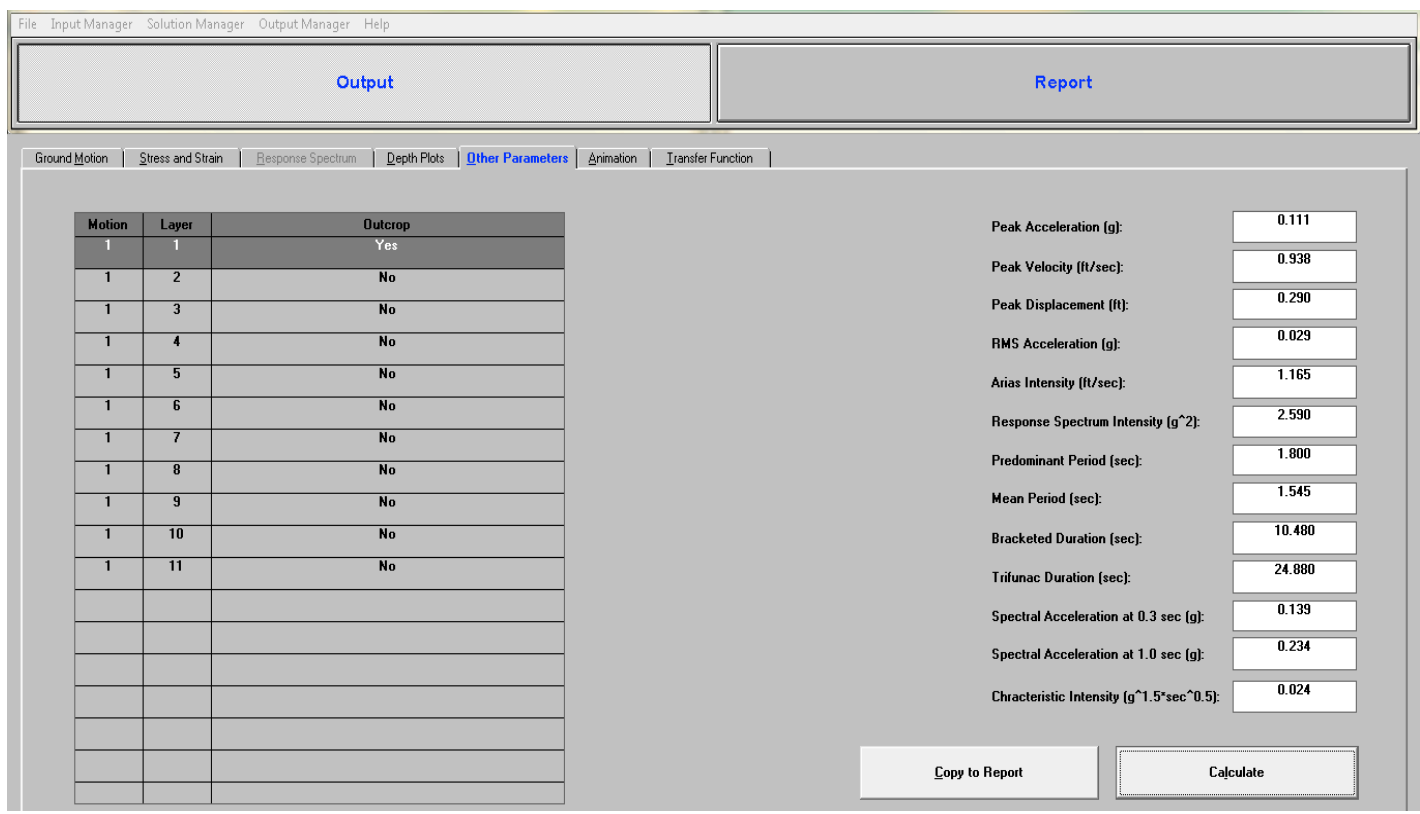

Gambar 9 Hasil kalkulasi edushake pada lapisan tanah untuk lokasi CPTu-1 


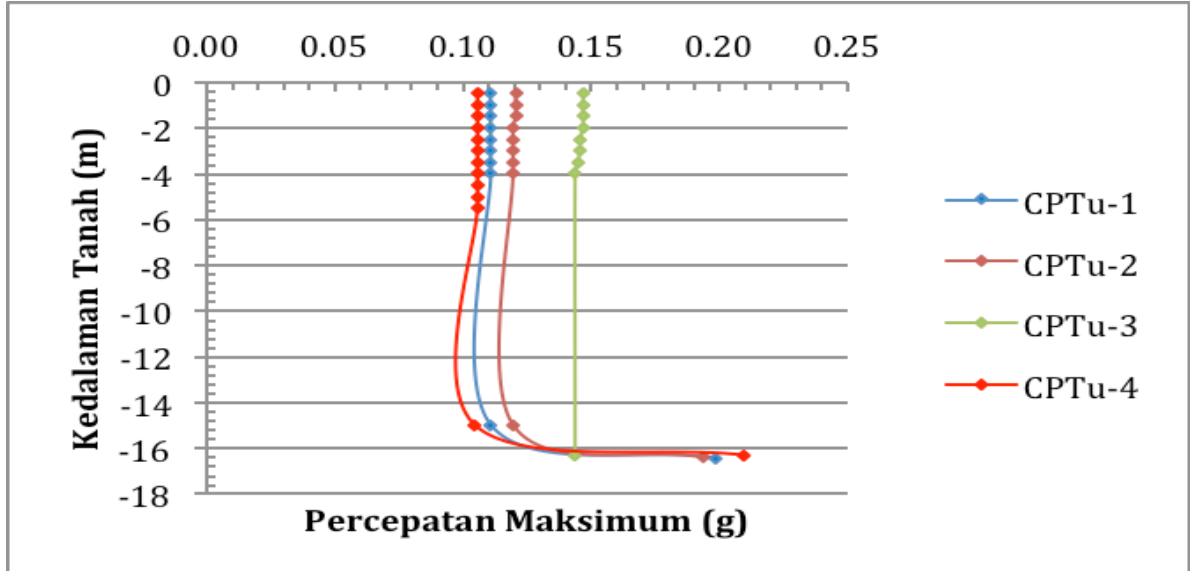

Gambar 10 Percepatan pada permukaan pada setiap lapisan tanah

\section{Perhitungan CSR ${ }_{M 7.5}, C R R_{M 7.5}$ dan Potensi Likuifaksi}

Tabel 7 Analisis pada lokasi CPTu-1

\begin{tabular}{|c|c|c|c|c|c|c|c|c|c|c|c|c|c|c|}
\hline $\begin{array}{c}\text { Kedalaman } \\
\text { (m) }\end{array}$ & Jenis Tanah & $\begin{array}{c}\text { Tebal } \\
\text { Tanah } \\
(\mathrm{m})\end{array}$ & $\begin{array}{c}\gamma \\
\left(\mathrm{KN} / \mathrm{m}^{3}\right)\end{array}$ & $\begin{array}{c}\gamma w \\
\left(K N / \mathbf{m}^{3}\right)\end{array}$ & $\begin{array}{c}\sigma_{\mathbf{v}} \\
\left(\mathrm{KN} / \mathrm{m}^{2}\right)\end{array}$ & $\begin{array}{c}\mu \\
\left(K N / \mathbf{m}^{2}\right)\end{array}$ & $\begin{array}{c}\sigma_{\prime}^{\prime} \mathbf{} \\
\left(K N / m^{2}\right)\end{array}$ & $\begin{array}{c}a_{\max } \\
(\mathrm{g})\end{array}$ & rd & CSR & $\operatorname{CSR}_{\mathrm{M}=7.5}$ & $\mathrm{C}_{\mathrm{Q}}$ & $\mathbf{q}_{\mathrm{clN}}$ & $\mathrm{CRR}_{\mathrm{M}==}$ \\
\hline-0.5 & Sand to silty sand & 0.5 & 14.92 & 0 & 7.46 & 0.00 & 7.46 & 0.111 & 1.00 & 0.072 & $0.00 J$ & 1.70 & 49.717 & 0.091 \\
\hline-1.0 & Sand to silty sand & 0.5 & 15.20 & 0 & 15.06 & 0.00 & 15.06 & 0.111 & 0.99 & 0.072 & 0.065 & 1.70 & 113.543 & 0.216 \\
\hline-1.5 & Sand to silty sand & 0.5 & 14.80 & 0 & 22.46 & 0.00 & 22.46 & 0.111 & 0.99 & 0.071 & 0.065 & 1.70 & 100.790 & 0.175 \\
\hline-2.0 & Sand to silty sand & 0.5 & .15 & 0 & 30.04 & 0.00 & 30.04 & 0.111 & 0.98 & 0.071 & 0.064 & 1.70 & 111.952 & 210 \\
\hline-2.5 & Sand to silty sand & 0.5 & 15.54 & 0 & 37.81 & 0.00 & 37.81 & 0.111 & 0.98 & 0.071 & 0.064 & 1.626 & 119.020 & 0.237 \\
\hline-3.0 & Sand to silty sand & 0.5 & 15.60 & 9.8 & 45.61 & 4.90 & 40.71 & 0.111 & 0.98 & 0.079 & 0.072 & 1.567 & 116.533 & 0.227 \\
\hline-3.5 & Sand to silty sand & 0.5 & 14.99 & 9.8 & 53.10 & 9.80 & 43.30 & 0.111 & 0.97 & 0.086 & 0.078 & 1.520 & 95.448 & 0.161 \\
\hline-4.0 & Sand to silty sand & 0.5 & 14.96 & 9.8 & 60.58 & 14.70 & 45.88 & 0.111 & 0.97 & 0.092 & 0.084 & 1.476 & 62.116 & 0.102 \\
\hline-15.0 & Clay & 11.0 & 14.77 & 9.8 & 223.05 & 122.50 & 100.55 & 0.111 & 0.77 & 0.124 & 0.112 & 0.997 & 3.087 & 0.053 \\
\hline-16.44 & Silty Clay to Clay & 1.44 & 14.99 & 9.8 & 244.64 & 136.61 & 108.03 & 0.199 & 0.74 & 0.215 & 0.195 & 0.962 & 3.845 & 0.053 \\
\hline
\end{tabular}

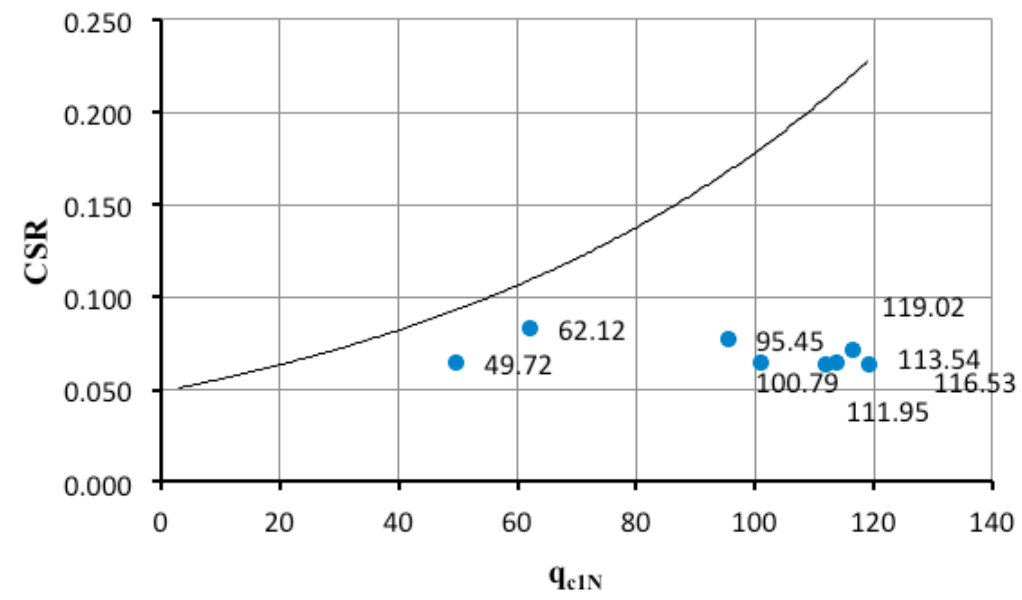

Gambar 11 Potensi likuifaksi pada titik CPTu-1 
Tabel 8 Hasil analisis potensi likuifaksi pada titik CPTu-1

\begin{tabular}{|l|l|l|l|l|}
\hline No. & Kedalaman & Tebal Tanah & Jenis Tanah & Ket. \\
\hline 1 & -0.5 & 0.5 & Sand to silty sand & NL \\
\hline 2 & -1 & 0.5 & Sand to silty sand & NL \\
\hline 3 & -1.5 & 0.5 & Sand to silty sand & NL \\
\hline 4 & -2 & 0.5 & Sand to silty sand & NL \\
\hline 5 & -2.5 & 0.5 & Sand to silty sand & NL \\
\hline 6 & -3 & 0.5 & Sand to silty sand & NL \\
\hline 7 & -3.5 & 0.5 & Sand to silty sand & NL \\
\hline 8 & -4 & 0.5 & Sand to silty sand & NL \\
\hline 9 & -15 & 11.0 & Clay & NL \\
\hline 10 & -16.44 & 1.44 & Silty Clay to Clay & NL \\
\hline
\end{tabular}

Keterangan :

Letak muka air tanah $-2.5 \mathrm{~m}$

NL : Nonlikuifaksi

L : Likuifaksi

Tabel 9 Analisis pada lokasi CPTu-2

\begin{tabular}{|c|c|c|c|c|c|c|c|c|c|c|c|c|c|c|}
\hline $\begin{array}{c}\text { Kedalaman } \\
\text { (m) }\end{array}$ & Jenis Tanah & $\begin{array}{c}\text { Tebal } \\
\text { Tanah } \\
(\mathrm{m}) \\
\end{array}$ & $\begin{array}{c}\gamma \\
\mathrm{KN} / \mathrm{m}^{3}\end{array}$ & $\begin{array}{c}\gamma \mathbf{W} \\
\mathbf{K N} / \mathbf{m}^{3}\end{array}$ & $\begin{array}{c}\sigma_{V} \\
\left(K N / \mathbf{m}^{2}\right)\end{array}$ & $\begin{array}{c}\mu \\
\left(K N / m^{2}\right)\end{array}$ & $\begin{array}{c}\sigma_{\mathbf{V}} \\
\left(\mathrm{KN} / \mathrm{m}^{2}\right)\end{array}$ & $\begin{array}{c}a_{\max } \\
(\mathrm{g})\end{array}$ & rd & CSR & $\operatorname{CSR}_{\mathrm{M}=7.5}$ & $\mathrm{C}_{\mathrm{Q}}$ & $\mathbf{q}_{\mathrm{elN}}$ & $\mathrm{CRR}_{\mathrm{M}=7.5}$ \\
\hline-0.5 & Sand to silty sand & 0.5 & 14.98 & 0 & 7.49 & 0.00 & 7.49 & 0.121 & 1.00 & 0.078 & 0.071 & 1.70 & 50.68 & 0.092 \\
\hline-1.0 & Sand to silty sand & 0.5 & 14.92 & 0 & 14.95 & 0.00 & 14.95 & 0.121 & 0.99 & 0.078 & 0.071 & 1.70 & 104.34 & 0.186 \\
\hline-1.5 & Sand to silty sand & 0.5 & 15.56 & 0 & 22.73 & 0.00 & 22.73 & 0.121 & 0.99 & \begin{tabular}{|l|}
0.078 \\
\end{tabular} & 0.070 & 1.70 & 125.25 & 0.263 \\
\hline-2.0 & Sand to silty sand & 0.5 & 17.34 & 9.8 & 31.40 & 4.90 & 26.50 & 0.120 & 0.98 & 0.091 & 0.082 & 1.70 & 182.66 & 0.647 \\
\hline-2.5 & Sand & 0.5 & 16.09 & 9.8 & 39.44 & 9.80 & 29.64 & 0.120 & 0.98 & 0.102 & 0.092 & 1.70 & \begin{tabular}{|l|}
142.21 \\
\end{tabular} & 0.347 \\
\hline-3.0 & Sand & 0.5 & 15.32 & 9.8 & 47.10 & 14.70 & 32.40 & 0.120 & 0.98 & 0.111 & 0.100 & 1.70 & 117.41 & 0.231 \\
\hline-3.5 & Sand & 0.5 & 15.52 & 9.8 & 54.86 & 19.60 & 35.26 & 0.120 & 0.97 & 0.118 & 0.107 & 1.68 & \begin{tabular}{|l|}
122.71 \\
\end{tabular} & 0.252 \\
\hline-4.0 & Sand & 0.5 & 14.87 & 9.8 & 62.30 & 24.50 & 37.80 & 0.120 & 0.97 & 0.125 & 0.113 & 1.63 & \begin{tabular}{|l|}
98.42 \\
\end{tabular} & 0.169 \\
\hline-15.00 & Clays & 11.00 & 15.03 & 9.8 & 227.58 & 132.30 & 95.28 & 0.120 & 0.77 & 0.144 & 0.131 & 1.02 & 4.21 & 0.054 \\
\hline-16.42 & Silty Clay to Clay & 1.42 & 14.99 & 9.8 & 248.87 & 146.22 & 102.65 & 0.194 & 0.74 & 0.225 & 0.204 & 0.99 & 3.91 & 0.053 \\
\hline
\end{tabular}

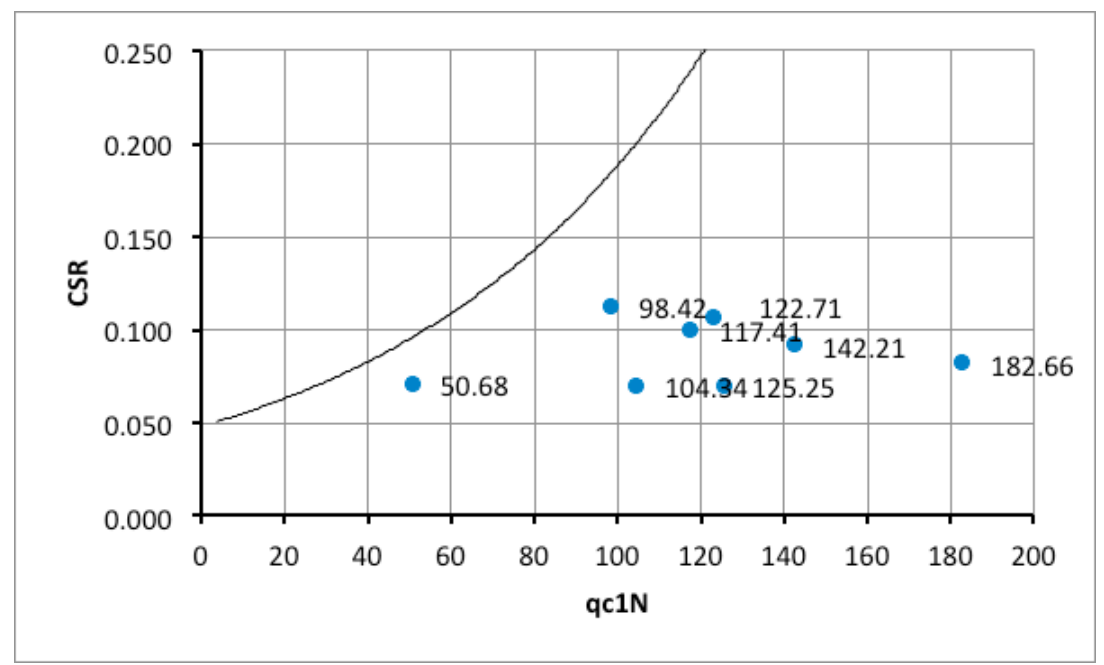

Gambar 12 Potensi likuifaksi pada titik CPTu-2 
Tabel 10 Hasil analisis potensi likuifaksi pada titik CPTu-2

\begin{tabular}{|l|l|l|l|l|}
\hline No. & Kedalaman & Tebal Tanah & Jenis Tanah & Ket. \\
\hline 1 & -0.5 & 0.5 & Sand to silty sand & NL \\
\hline 2 & -1.0 & 0.5 & Sand to silty sand & NL \\
\hline 3 & -1.5 & 0.5 & Sand to silty sand & NL \\
\hline 4 & -2.0 & 0.5 & Sand to silty sand & NL \\
\hline 5 & -2.5 & 0.5 & Sand & NL \\
\hline 6 & -3.0 & 0.5 & Sand & NL \\
\hline 7 & -3.5 & 0.5 & Sand & NL \\
\hline 8 & -4.0 & 0.5 & Sand & NL \\
\hline 9 & -15.00 & 11.00 & Clays & NL \\
\hline 10 & -16.42 & 1.42 & Silty Clay to Clay & NL \\
\hline
\end{tabular}

Keterangan :

Letak muka air tanah $-1.5 \mathrm{~m}$

NL : Nonlikuifaksi

L : : Likuifaksi

Tabel 11 Analisis pada lokasi CPTu-3

\begin{tabular}{|c|c|c|c|c|c|c|c|c|c|c|c|c|c|c|}
\hline $\begin{array}{l}\text { Kedalaman } \\
\text { (m) }\end{array}$ & Jenis Tanah & \begin{tabular}{|c|} 
Tebal \\
Tanah \\
$(\mathrm{m})$
\end{tabular} & $\begin{array}{c}\gamma \\
K N / m^{3}\end{array}$ & $\begin{array}{c}\gamma \mathbf{W} \\
\mathbf{K N} / \mathbf{m}^{3}\end{array}$ & $\begin{array}{c}\sigma_{\mathrm{V}} \\
\left(\mathrm{KN} / \mathrm{m}^{2}\right)\end{array}$ & $\begin{array}{c}\mu \\
\left(K N / \mathbf{m}^{2}\right)\end{array}$ & $\begin{array}{c}\sigma_{\mathbf{v}}^{\prime} \\
\left(\mathrm{KN} / \mathbf{m}^{2}\right)\end{array}$ & $\underset{(g)}{\operatorname{amax}}$ & rd & CSR & $\mathrm{CSR}_{\mathrm{M}=7.5}$ & $\mathrm{C}_{\mathrm{Q}}$ & $\mathbf{q}_{\mathrm{c} 1 \mathrm{~N}}$ & $\mathrm{CRR}_{\mathrm{M}=7.5}$ \\
\hline-0.5 & Sand to silty sand & 0.5 & 14.15 & 0 & 7.07 & 0.00 & 7.07 & 0.147 & 1.00 & 0.095 & 0.086 & 1.70 & 74.303 & 0.118 \\
\hline-1.0 & Sand to silty sand & 0.5 & 17.26 & 0 & 15.70 & 0.00 & 15.70 & 0.147 & 0.99 & 0.095 & 0.086 & 1.70 & 179.969 & 0.622 \\
\hline-1.5 & Sand to silty sand & 0.5 & 15.85 & 0 & 23.63 & 0.00 & 23.63 & 0.147 & 0.99 & 0.094 & 0.086 & 1.70 & 134.514 & 0.306 \\
\hline-2.0 & Sand to silty sand & 0.5 & 14.90 & 0 & 31.08 & 0.00 & 31.08 & 0.147 & 0.98 & 0.094 & 0.085 & 1.70 & 103.996 & 0.185 \\
\hline-2.5 & Sand to silty sand & 0.5 & 14.78 & 9.8 & 38.47 & 4.90 & 33.57 & 0.146 & 0.98 & 0.107 & 0.097 & 1.70 & 100.055 & 0.173 \\
\hline-3.0 & Sand to silty sand & 0.5 & 14.12 & 9.8 & 45.53 & 9.80 & 35.73 & 0.146 & 0.98 & 0.118 & 0.107 & 1.673 & 77.498 & 0.123 \\
\hline-3.5 & Sand to silty sand & 0.5 & 13.84 & 9.8 & 52.45 & 14.70 & 37.75 & 0.145 & 0.97 & 0.127 & 0.115 & 1.628 & 66.496 & 0.107 \\
\hline-4.0 & Sand to silty sand & 0.5 & 14.86 & 9.8 & 59.88 & 19.60 & 40.28 & 0.144 & 0.97 & 0.135 & 0.122 & 1.576 & \begin{tabular}{|l|l|}
95.164 \\
\end{tabular} & 0.160 \\
\hline-16.35 & Clays & 12.35 & 15.39 & 9.8 & 249.93 & 140.63 & 109.30 & 0.144 & 0.74 & 0.158 & 0.143 & 0.956 & 5.314 & 0.054 \\
\hline
\end{tabular}

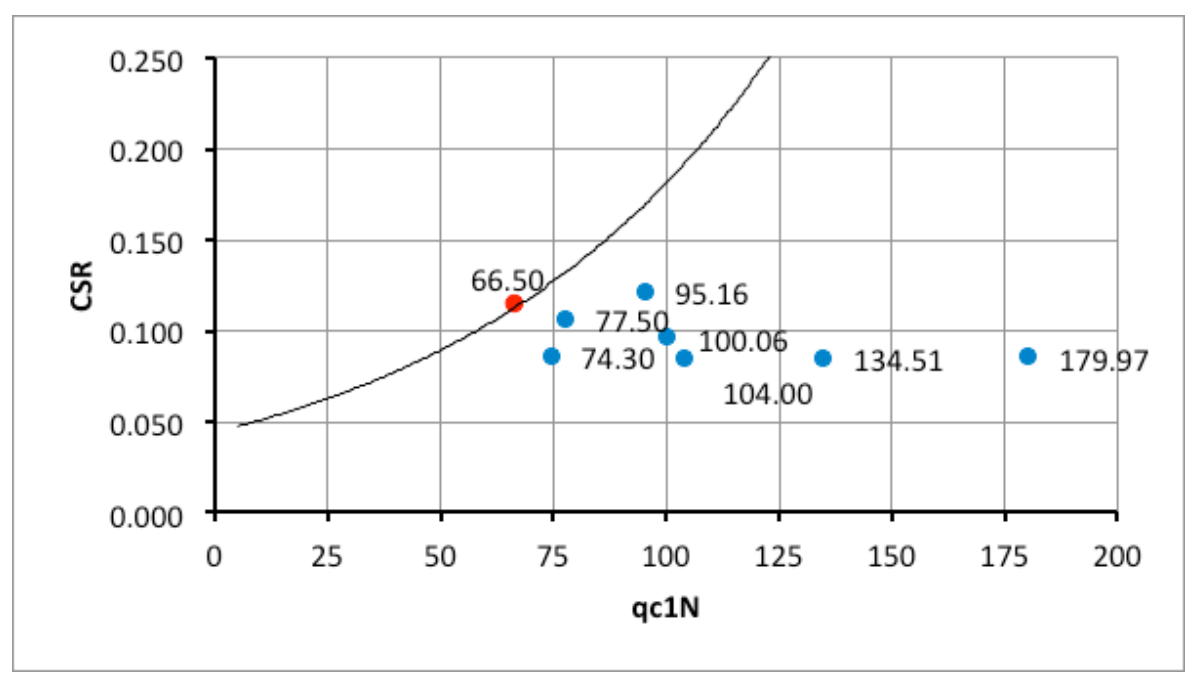

Gambar 13 Potensi likuifaksi pada titik CPTu-3 
Tabel 12 Hasil analisis potensi likuifaksi pada titik CPTu-3

Keterangan :

\begin{tabular}{|l|l|l|l|l|}
\hline No. & Kedalaman & Tebal Tanah & Jenis Tanah & Ket. \\
\hline 1 & -0.5 & 0.5 & Sand to silty sand & $\mathrm{NL}$ \\
\hline 2 & -1.0 & 0.5 & Sand to silty sand & $\mathrm{NL}$ \\
\hline 3 & -1.5 & 0.5 & Sand to silty sand & $\mathrm{NL}$ \\
\hline 4 & -2.0 & 0.5 & Sand to silty sand & $\mathrm{NL}$ \\
\hline 5 & -2.5 & 0.5 & Sand to silty sand & $\mathrm{NL}$ \\
\hline 6 & -3.0 & 0.5 & Sand to silty sand & $\mathrm{NL}$ \\
\hline 7 & -3.5 & 0.5 & Sand to silty sand & $\mathrm{L}$ \\
\hline 8 & -4.0 & 0.5 & Sand to silty sand & $\mathrm{NL}$ \\
\hline 9 & -16.35 & 12.35 & Clays & $\mathrm{NL}$ \\
\hline
\end{tabular}

Letak muka air tanah $-2 \mathrm{~m}$

NL : Nonlikuifaksi

L : : Likuifaksi

Tabel 13 Analisis pada lokasi CPTu-4

\begin{tabular}{|c|c|c|c|c|c|c|c|c|c|c|c|c|c|c|}
\hline $\begin{array}{c}\text { Kedalaman } \\
\text { (m) }\end{array}$ & h & \begin{tabular}{|c|} 
Tebal \\
Tanah \\
$(\mathbf{m})$ \\
\end{tabular} & $\begin{array}{c}\gamma \\
K N / m^{3}\end{array}$ & $\begin{array}{c}\gamma \mathbf{W} \\
\mathbf{K N} / \mathbf{m}^{3}\end{array}$ & $\begin{array}{c}\sigma_{\mathbf{V}} \\
\left(K N / m^{2}\right)\end{array}$ & $\begin{array}{c}\mu \\
\left(K \mathbf{K} / \mathbf{m}^{2}\right)\end{array}$ & $\begin{array}{c}\sigma_{v}^{\prime} \mathbf{v} \\
\left(K N / \mathbf{m}^{2}\right)\end{array}$ & $\underset{(g)}{\operatorname{amax}}$ & rd & CSR & $\operatorname{CSR}_{\mathrm{M}=7.5}$ & $\mathrm{C}_{\mathbf{Q}}$ & $\mathbf{q}_{\mathrm{c} 1 \mathrm{~N}}$ & $\mathrm{CRR}_{\mathrm{M}=}$ \\
\hline-0.50 & ind to silty sand & 0.50 & .08 & 0 & 7.54 & 0.00 & 7.54 & 0.106 & 1.00 & 0.069 & .002 & 1.70 & 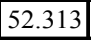 & 0.075 \\
\hline-1.00 & Sand to silty sand & 0.50 & 14.55 & 0 & 14.81 & 0.00 & 14.81 & 0.106 & 0.99 & 0.068 & 0.062 & 1.70 & 92.480 & 0.154 \\
\hline-1.50 & Sand to silty sand & 0.50 & 15.67 & 9.8 & 22.65 & 4.90 & 17.75 & 0.106 & 0.99 & 0.087 & 0.079 & 1.70 & 62.322 & .103 \\
\hline-2.00 & Sand to silty sand & 0.50 & 14.67 & 9.8 & 29.98 & 9.80 & 20.18 & 0.106 & 0.98 & 0.101 & 0.091 & \begin{tabular}{|l|}
1.70 \\
\end{tabular} & 45.414 & 0.088 \\
\hline-2.50 & Sand to silty sand & 0.50 & 14.05 & 9.8 & 37.01 & 14.70 & 22.31 & 0.106 & 0.98 & 0.112 & .102 & 1.70 & $76.361 \mid$ & .121 \\
\hline-3.00 & Sand to silty sand & 0.50 & 13.85 & 9.8 & 43.93 & 19.60 & 24.33 & 0.106 & 0.98 & 0.122 & 0.110 & 1.70 & 70.040 & 0.112 \\
\hline-3.50 & Sand to silty sand & 0.50 & 15.01 & 9.8 & 51.44 & 24.50 & 26.94 & 0.106 & 0.97 & 0.128 & 0.116 & \begin{tabular}{|l|}
1.70 \\
\end{tabular} & 51.201 & 0.092 \\
\hline-4.00 & Sand to & 0.50 & 15.36 & 9.8 & 59.12 & 29.40 & 29.72 & 0.106 & 0.97 & 0.133 & 0.120 & 1.70 & 57.120 & 0.097 \\
\hline-4.50 & Sand to silty sand & 0.50 & 14.89 & 9.8 & 66.56 & 34.30 & 32.26 & 0.106 & 0.97 & 0.137 & 0.124 & 1.70 & 49.045 & 0.091 \\
\hline-5.00 & Sand to silty sand & 0.50 & 14.18 & 9.8 & 73.65 & 39.20 & 34.45 & 0.106 & 0.96 & 0.142 & 0.128 & 1.70 & 36.982 & 0.081 \\
\hline-5.50 & Sand to silty sand & 0.50 & 13.95 & 9.8 & 80.62 & 44.10 & 36.52 & 0.106 & 0.96 & 0.146 & 0.132 & 1.655 & 32.185 & 0.077 \\
\hline-15.00 & Clays & 9.50 & 14.79 & 9.8 & 221.09 & 137.20 & 83.89 & 0.105 & 0.77 & 0.139 & 0.126 & 1.092 & 3.431 & 0.053 \\
\hline-16.32 & Silty clay to clay & 1.32 & 15.11 & 9.8 & 241.03 & 150.14 & 90.90 & 0.210 & 0.74 & 0.267 & 0.242 & 1.049 & 4.653 & 0.054 \\
\hline
\end{tabular}

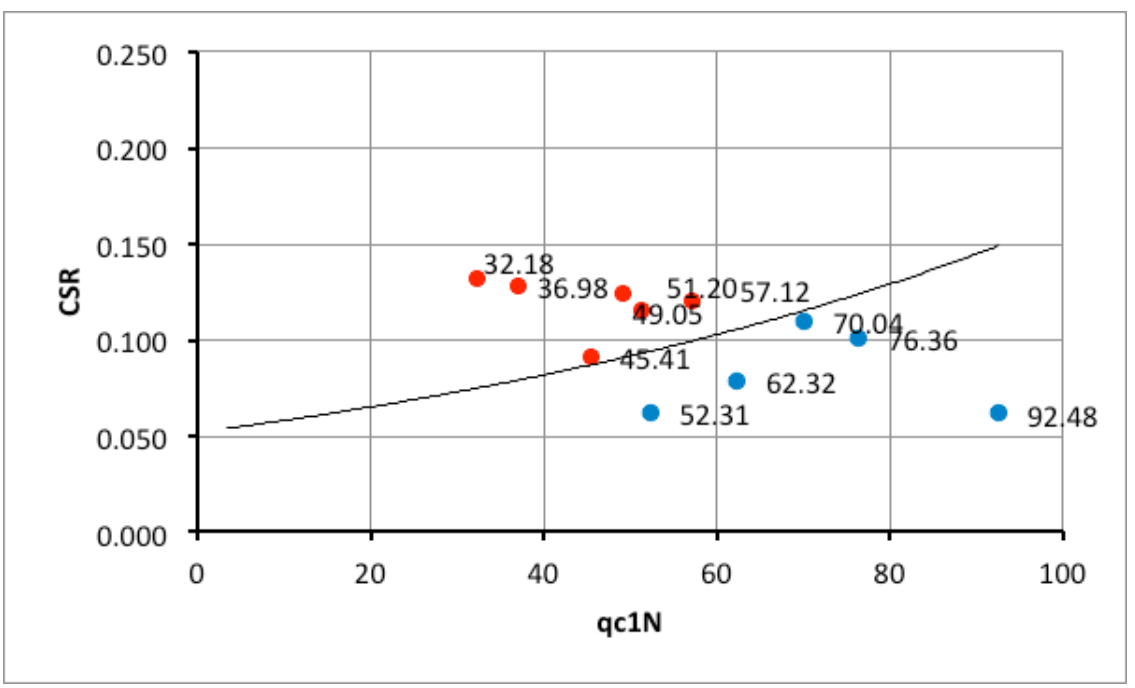

Gambar 14 Potensi likuifaksi pada titik CPTu-4 
Tabel 14 Hasil analisis potensi likuifaksi pada titik CPTu-4

Keterangan :

\begin{tabular}{|l|l|l|l|l|}
\hline No. & Kedalaman & Tebal Tanah & Jenis Tanah & Ket. \\
\hline 1 & -0.50 & 0.50 & Sand to silty sand & NL \\
\hline 2 & -1.00 & 0.50 & Sand to silty sand & NL \\
\hline 3 & -1.50 & 0.50 & Sand to silty sand & NL \\
\hline 4 & -2.00 & 0.50 & Sand to silty sand & $\mathrm{L}$ \\
\hline 5 & -2.50 & 0.50 & Sand to silty sand & NL \\
\hline 6 & -3.00 & 0.50 & Sand to silty sand & NL \\
\hline 7 & -3.50 & 0.50 & Sand to silty sand & $\mathrm{L}$ \\
\hline 8 & -4.00 & 0.50 & Sand to silty sand & $\mathrm{L}$ \\
\hline 9 & -4.50 & 0.50 & Sand to silty sand & $\mathrm{L}$ \\
\hline 10 & -5.00 & 0.50 & Sand to silty sand & $\mathrm{L}$ \\
\hline 11 & -5.50 & 0.50 & Sand to silty sand & $\mathrm{L}$ \\
\hline 12 & -15.00 & 9.50 & Clays & NL \\
\hline 13 & -16.32 & 1.32 & Silty clay to clay & NL \\
\hline
\end{tabular}

Letak muka air tanah $-1 \mathrm{~m}$

NL : Nonlikuifaksi

L : Likuifaksi

\section{Kesimpulan}

Berdasarkan hasil analisis potensi likuifaksi pada area Reklamasi Pelabuhan Kontainer Belawan, maka dapat diambil kesimpulan sebagai berikut :

- Percepatan puncak pada batuan dasar berdasarkan Peta Hazard Gempa Indonesia 2010 pada lokasi penelitian adalah $0.213 \mathrm{~g}$.

- Nilai percepatan pada permukaan di setiap lapisan tanah mengalami perkecilan (deamplifikasi), bila terjadi pergerakan dari batuan dasar (dengan PGA $0.213 \mathrm{~g}$ ) dengan karakteristik gempa Elcentro.

- Dari hasil analisis, lapisan pasir yang berpotensi terjadi likuifaksi pada area Reklamasi Pelabuhan Kontainer Belawan adalah :

a. CPTu-3 kedalaman $3.5 \mathrm{~m}$

b. CPTu-4 kedalaman $2 \mathrm{~m}$ dan $3.5-5.5 \mathrm{~m}$

c. CPTu-11 kedalaman $3-4 \mathrm{~m}$

d. CPTu-12 kedalaman $3.5-4.5 \mathrm{~m}$

e. CPTu-13 kedalaman $0.5-3.5 \mathrm{~m}$

f. CPTu-19 kedalaman $0.5 \mathrm{~m}$

g. CPTu-20 kedalaman $4 \mathrm{~m}$

Sedangkan pada CPTu-1, CPTu-2 dan CPTu-10 tidak terjadi likuifaksi pada lapisan pasir.

- Berdasarkan hasil analisis tersebut, secara umum dapat disimpulkan bahwa lapisan lapisan pasir pada area Reklamasi Pelabuhan Kontainer Belawan berpotensi likuifaksi jika terjadi gempa dengan magnitude $6.9 \mathrm{M}$ sesuai karakteristik gempa Elcentro. 
- Analisis potensi likuifaksi pada penelitian ini dilakukan berdasarkan data penyelidikan tanah yaitu CPTu. Di mana kondisi reklamasi pada saat pengujian $\mathrm{CPTu}$ masih dalam tahap preloading dan prefabrecated vertical drain (PVD), sehingga kondisi reklamasi belum terkonsolidasi sempurna. Dengan demikian disarankan untuk mengkaji ulang potensi likuifaksi pada Area Reklamasi Pelabuhan Kontainer Belawan, setelah tahapan preloading dan PVD selesai dengan data penyelidikan tanah yang terbaru.

\section{Daftar Pustaka}

Das, B. M. (2010). Principles of Geotechnical Engineering, Stamford, Connecticut: Cengage Learning.

Hasmar, A. H. (2007). Evaluasi Potensial Likuifaksi Akibat Gempa Bumi Tektonik Lapisan Pasir Jenuh Air dengan Metode Shaking Table (Studi Kasus Pasir Kali Krasak Yogyakarta). Logika. $4(1)$.

Irsyam, M. (2006). Pengantar Dinamika Tanah dan Rekayasa Gempa. Bandung: ITB.

Harahap, I. S., \& Rudi, I. Rekonturing Zona Percepatan Gempa Di Permukaan Tanah Propinsi Sumatera Utara Dengan Program Aplikasi Shake 2000 (Tesis Master). Diakses dari Perpustakaan Universitas Sumatera Utara, Medan.

Sinaga, J. Frans Bolmen. (2013). Analisis Potensi Likuifaksi Pada Proyek Ware House Belawan (Skripsi Sarjana). Diakses dari perpustakaan Universitas Sumatera Utara, Medan.

Seed, H. B., \& Idriss, I. M. Simplified Procedure for Evaluating Soil Liquefaction Potential. Journal of the Soil Mechanics and Foundations Division, 97(9), 1249-1273.

Youd, T. L., \& Idriss, I. M. (2001). Liquefaction resistance of soils: summary report from the 1996 NCEER and 1998 NCEER/NSF workshops on evaluation of liquefaction resistance of soils. Journal of geotechnical and geoenvironmental engineering, 127(4), 297-313. 
